\title{
Kahramanmaraş İlinde Yetiştirilen Biberlerde Biber Bakteriyel Leke Hastalığı Etmeninin Belirlenmesi
}

\author{
Ayşegül ŞAHİN $^{1 *}$, Mustafa KÜSEK $^{1 * *}$ \\ ${ }^{1}$ KSÜ, Ziraat Fakültesi, Bitki Koruma Bölümü, Kahramanmaraş
}

Geliş (Received): 02.06.2015

Kabul (Accepted): 08.09.2015

\begin{abstract}
ÖZET: Bu çalışmada biberin yoğun olarak yetiştirildiği Gaziantep ve Kahramanmaraş illerinde biber bakteriyel leke hastalığı simptomu gösteren bitkilerden bakteriyel etmenler izole edilmiştir. Elde edilen bu bakterilerin morfolojik, fizyolojik ve biyokimyasal özelliklerine göre klasik tanılaması yapılmıştır. Yapılan çalışmalar sonucunda sürvey alanlarındaki biber bitkilerinden izole edilen 103 bakteri izolatının 100 tanesi Xanthomonas axonopodis pv. axonopodis olduğu belirlenmiş̧ir.
\end{abstract}

Anahtar Kelimeler: Tanılama, biber, Xanthomonas axonopodis pv. axonopodis

\section{Determination of Pepper Bacterial Spot Disease Agent on Pepper Plants Growing in Kahramanmaras Province}

ABSTRACT: In this study, bacterial agents were isolated from pepper plants showing symptoms of bacterial spot disease in Gaziantep and Kahramanmaras provinces. The obtained bacterial isolates were identified according to the classical, diagnostic procedures such as morphology, physiological and biochemical characteristics. From pepper plants 103 bacterial strain were isolated and 100 bacterial colonies of these isolates were determined as Xanthomonas axonopodis pv. axonopodis.

Key Words: Diagnostics, pepper, Xanthomonas axonopodis pv. axonopodis

\section{GIRIŞ}

Biber (Capsicum annuum L.), Solanaceae familyasından ve sebze olarak tüketilen önemli bir kültür bitkisidir. Biberin anavatanının tropikal Amerika olup, buradan dünyaya yayıldı ̆̆ı bilinmektedir. Biberin ana vatanı Tropik Güney Amerika olup, en fazla yetiştiği ülke Brezilya'dır. Biber dünyaya önce İspanya'ya, oradan da 1548 yılında İngiltere'ye, daha sonra da Orta Avrupa ve diğer Avrupa ülkelerine girmiştir. Balkan ülkelerinden sonra ülkemize ve Orta ve Kuzey Afrika ülkelerine yayılmıştır (Anonim, 2009).

Ülkemiz için önemli bir gelir kaynağı olan biberin fitopatolojik açıdan en önemli sorunlarından birisi, Xanthomonas sp'nin neden olduğu bakteriyel leke hastalığıdır (Aysan ve Şahin, 2003). Biberde bakteriyel leke hastalığının ilk simptomları yaprak kenarlarında ortaya çıkmaktadır. Biber bitkilerinin yaprak, meyve sapı ve taç yapraklar hastalığa en duyarlı yerler olduğu, yaprakta önce küçük sarı-yeşil, etrafı sarımsı bir hale ile çevrili lekelerin, nemli koşullarda su emmiş alanlar şeklini aldığı bildirilmektedir. Daha sonra lekelerin birleşerek merkezi kahverengi-siyah olan genel bir sarılık simptomu meydana getirdiği gözlenmektedir. Hastalık gövdede önce hafif sulu ve sarımsı, zamanla koyu kahverengi ve üzeri derin çatlaklar oluşmuş nekrotik alanlar şeklinde ortaya çıkar. Meyvedeki bakteriyel lekeler başlangıçta küçük, kabarcık benzeri ve düzenlidir, daha sonra kahverengileşir ve siğilimsi bir görünüm alarak meyvede şekil bozukluklarına neden olurlar (Şahin, 1997; Aysan ve Çınar, 2001).

Biber bakteriyel leke hastalığı bitki büyümesini yavaşlatıp, meyve verimini ve kalitesini düşürerek zarar meydana getirir. Hastalığın yoğun olarak ortaya çıktığı durumlarda, meyve ağırlığında \%52'ye varan ürün kayıplarına neden olduğu bildirilmektedir. Hastalık şiddetine ve bitki yaşına bağlı olarak verim kaybının genç bitkide olgun bitkiye göre daha fazla olabileceği birçok araştırmacı tarafindan belirtilmiştir (Cook ve Stall, 1982; Cook ve Baker, 1983; Jones ve ark, 1986; Pohronezny ve ark, 1992).

Biber bakteriyel leke hastalığının meydana gelmesindeki en önemli etken nemdir. Tohum ve toprak kökenli olan hastalık canlılığını konukçu bitkiler üzerinde, toprakta ve bitki artıklarında sürdürür (Mirik, 2005). Hastalıkla mücadelede hastalıklı tohum kullanımının engellenmesinin yanı sıra konukçu bitkilerden gelen hastalık kaynağının da yok edilmesi gereklidir (Saygılı ve ark, 1985; Stall,1993). Ayrıca biber yetiştiriciliğinin yaygın olarak yapıldığ 1 bölgelerde inokulumun sürekli olarak artmaması için 3 yıllık bir ürün rotasyonu yapılması önerilmektedir (Stall,1993).

Xanthomonas'lar bitkinin koruyucu tabaka olan kütiküla'yı geçecek aktif bir mekanizması bulunmamaktadır. Bundan dolayı bakteri konukçu bitkiye sadece yaralar ve doğal açıklıklardan girebilmektedir (Mirik,2005).

Xanthomonas cinsine ait bakteriler Gram negatif, genellikle çubuk şeklinde, 0,2-0,6 $\mu \mathrm{m}$ eninde 0,8-2,9 $\mu \mathrm{m}$ boyundadır. Hareketli ve hareketsiz olanları vardır. Hareketli olanlar polar monotrik kamçılara sahiptirler (Mirik,2005). Xanthomonas cinsine ait bakteriler sıcağ 1 seven bakterilerdir ve optimum gelişme sıcaklığı 25$30^{\circ} \mathrm{C}$ 'dir. Aerob oldukları için oksijensiz ortamda

\footnotetext{
*Ayşegül ŞAHIN' 'in yüksek lisans tezinden hazırlanmıştır.

**Sorumlu Yazar: Küsek, M., mkusek@ksu.edu.tr
} 
gelişemezler (Mirik, 2005). Diğer Gram negatif bakterilerde olduğu gibi hücre duvarı dış membran ile çevrilmiştir. Diş membranın yapısı çeșitli proteinlerden, lipopolisakkaritlerden (LPS) ve lipitlerden oluşmuştur. Dış yapı her tür için spesifik ve bu özellik virülenslikte önemli rollere sahiptir. En dişta ise bakteri hücresi xanthan adı verilen sümüğümsü bir tabaka olan ekstraselülarpolisakkarit (EPS) ile çevrilidir. D1ş membranın görevi bakteriyi kötü çevre koşullarına karşı korumak ve bitkideki bağlanma yerlerini tanımaktır (Mirik, 2005). Xanthomonas türlerinin çoğu en basit besi yeri olan Nutrient Agar (NA) besi yerinde kolaylıkla gelişir.

Bu çalışmada pul biberin yoğun olarak yetiştirildiği, Gaziantep, Kahramanmaraş illerinde biber bakteriyel leke hastalığ 1 etmeninin izolasyonu ve izole edilen izolatların morfolojik, fizyolojik ve biyokimyasal yöntemlerle bakteri türlerinin belirlenmesi yapılmıştır.

\section{MATERYAL ve YÖNTEM}

\section{Materyal}

Çalıșmanın ana materyalini Kahramanmaraș ve Gaziantep illerindeki biber üretim alanlarından toplanan hastalık simptomlarının görüldüğü biber örneklerden izole edilen bakteriyel izolatlar, referans izolatlar (1a-22r (Mustafa MIRIK, Namık Kemal Üniversitesi), GSPB2097(Gottinger Sammlung phytopathogener Bakterien, Georg August University Gottingen, Germany), NCPPB1395 (National Collection of Plant Pathogenic Bacteria, Harpenden, England), ECC1025, Pat erw), patojenite çalışmalarında biber Capsicum annum L., tütün (Nicotiana tabacum cv Samsun N) bitkileri kullanılmıştır.

\section{Yöntem}

Kahramanmaraş ve Gaziantep illerinde AğustosEylül aylarında biber üretim alanları incelenerek yapraklarda ve meyveler üzerinde nekrotik simptom gösteren bitkilerden örnekler alınmıștır. Taze hastalıklı bitki örnekleri alınıp, gazete kağıdına sarıldıktan sonra plastik torbalara etiketlenerek konulmuş ve buz kutusu içerisinde laboratuvara getirilmiștir. Laboratuvara getirilen örneklerden bir bisturi ile hastalıklı ve sağlıklı bölgeyi içerecek şekilde küçük bir kesit alınmış ve \%70 alkol emdirilmiş bir pamuk arasında 30-40 saniye bekletilmiștir. $\mathrm{Bu}$ parçalar daha sonra bir steril havan içerisinde ezilmiş ve üzerine steril fizyolojik su $(\% 0,85$ $\mathrm{NaCl}$ ) ilave edilerek homojenize edilmiştir. Homojeize edilmiş örnek 15-20 dk bekletildikten sonra bir öze alınarak içinde King B ve YDCA besiyeri (Lellito ve Stead, 1987) bulunan petrilere ekim yapılmış ve petriler $25 \pm 1^{\circ} \mathrm{C}$ 'de 48 saat inkübatörde inkübe edilmiştir Gelişen sarı renkli koloniler saflaştırılıncaya kadar ayn besi yerinde tekrar kültüre alınmıștır. Elde edilen izolatlar daha sonra çalışmalarda kullanılmak üzere eğik olarak hazırlanmış YDC agar besi yerinde $+4^{\circ} \mathrm{C}$ 'de buzdolabında ve \%15 gliserin içerisinde $-20{ }^{\circ} \mathrm{C}$ ' $\mathrm{de}$ saklanmıştır.
Bakteriyel izolatlar King B, YDC ve Nutrient Agar (NA) besiyerinde (Lellito ve Stead, 1987) 48 saat $25^{\circ} \mathrm{C}$ 'de inkübe edilmiş ve daha sonra koloni gelișimi incelenerek koloni özellikleri kaydedilmiştir. Tween B besi yerinde bakteriyel izolatlar 7-14 gün $25^{\circ} \mathrm{C}$ 'de kültüre alınmış ve dairesel tümsek beyaz kristalize bir alanla çevrili sarı koloni gelişimi gösteren izolatlar pozitif olarak değerlendirilmiştir (McGuire ve ark, 1986).Bakterilerin koloni özelliklerini belirlemede referans izolat olarak 1a-2 2r, GSPB2097 PCİC, NCPPB1395, ECC1025 izolatlar kullanılmıștır.

Potasyum hidroksit $(\mathrm{KOH})$ testinde \%3'lük potasyum hidroksit solüsyonu lam üzerine bir damla damlatılmış ve biber bakteriyel yaprak leke izolatları bir özeyle alınmış ve solüsyonda dairesel hareketlerle karıştırılmıştır. Daha sonra öze yukarı kaldırıldığında viskoz, yapışkanımsıbir sünme gösteren bakteri izolatları Gram negatif olarak değerlendirilmiştir (Sands, 1990).

Oksidaz testinde Taze hazırlanan \%1'lik N; N; N; N' - Tetramethyl- 1.4 phenylene diammonium diclorid eriği steril filtre kağıdına damlatılmıstır. Biber bakteriyel leke izolatlarının 48 saatlik kültürü kürdanile sslak kurutma kağıdına çizildiğinde 10 saniye içinde koyu mor renk oluşturan izolatlar pozitif olarak değerlendirilmiştir (Kovaks, 1956).

Oksidatif/Fermantatif(O/F) testinde hastalıklı bitki dokularından izole edilen bakterilerin oksidatiffermantatif özelliğini belirlemek için $2 \mathrm{~g}$ pepton, $5 \mathrm{~g}$ NaCI， 0,3g $\mathrm{KH}_{2} \mathrm{PO}_{4}, 3 \mathrm{~g}$ agar, $3 \mathrm{ml} \% 1$ 'lik bromothymol blue ve $1000 \mathrm{ml} \mathrm{H}_{2} \mathrm{O}$ içeren besi yeri hazırlandiktan sonra tüplere 5'er ml konulmuştur. Besi yeri $121^{\circ} \mathrm{C}$ 'de otoklavda steril edildikten sonra $50^{\circ} \mathrm{C}$ 'ye kadar soğutulan tüplerin her birine soğuk sterilizasyon yapılmıs olan \%10'luk glikoz solüsyonundan $0,5 \mathrm{ml}$ ilave edilmiştir. NA besiyerinde $25^{\circ} \mathrm{C}$ 'de 48 saat geliştirilen bakteri izolatları bir metal çubuk ile tüp içindeki besi yerinin içine inokule edilmiștir. Her bir izolat için 6 tüp kullanılmıștır. Bu tüplerden üçüne $1 \mathrm{ml}$ steril 1lık vaspar (Bir ölçü vazelin üç ölçü parafin karışımı) konarak yüzeyi kapatılmış diğer üçüne hiçbir ekleme yapılmamıștır. İnokule edilen tüpler $25^{\circ} \mathrm{C}$ 'de 5-6 günlük bir inkübasyondan sonra vaspar ilave edilen tüplerin rengi sarıya dönenleri fermentatif, sadece vasparsız besi yerinde sarıya dönenler ise oksidatif olarak değerlendirilmiștir (Sands, 1990).

Hastalıklı bitkilerden izole edilen bakteriyel etmenlerin nişastayı hidrolize etme özelliğini belirlemek için NA besiyeri içerisine $\% 2$ oranında eriyebilir nişasta ilave edilmiştir. Bunun için 10-20 ml distile suda nişasta 1sıtılarak çözüldükten sonra NA besi yerine ilave edilmiş ve $121^{\circ} \mathrm{C}$ 'de 15 dakika otoklav edilip steril petrilere dökülmüştür. Besi yerine çizilen bakteri izolatları 7-14 gün $25^{\circ} \mathrm{C}$ 'de inkübasyondan sonra kültürler üzerine lugol eriği ( $1 \mathrm{~g}$ iyot ve $2 \mathrm{~g} \mathrm{KI} 300 \mathrm{ml}$ distile suda eritilmiş) dökülmüştür. Nişastanın hidrolizasyonu bakteri kolonisinin etrafında meydana gelen boyanmamış alanın izlenmesiyle saptanmıștır. 
Pozitif kontrol olarak 1a-2 2r, GSPB2097 PCİC, NCPPB1395, ECC1025 bakteri izolatları kullanılmıştır.

Katalaz testinde NA besi yerinde bakteriyel izolatlar $25^{\circ} \mathrm{C}$ 'de 24 saat geliştirildikten sonra bir öze dolusu bakteri alınarak steril bir lam üzerine taşınmış ve üzerlerine $1 \mathrm{ml} \%$ 3'lük hidrojen peroksit dökülmüştür. Lam üzerindeki bakteriyel izolatlar üzerine hidrojen peroksit döküldükten birkaç saniye içinde katalaz aktivitesi sonucu açığa çıkan oksijen kabarcıkları gözlenen izolatlar pozitif olarak değerlendirilmiştir. Pozitif kontrol olarak 1a-2 2r, GSPB2097 PCİC, NCPPB1395, ECC1025 bakteri izolatları kullanılmıştır.

Pektolitik aktivite testinde patates yumruları kullanılmıştır. Steril bir bisturi ile kabukları soyulmuştur. Steril 1slak filtre kağıdı içeren steril petri içine kabuğu soyulmuş ve yaklaşık bir cm kalınlığındaki patates dilimleri kesilerek yerleştirilmiştir. Bir öze dolusu bakteri kültürü patates dilimi üzerine inokule edilmiştir. Steril petrilerde inokule edilmiş patates dilimleri $25^{\circ} \mathrm{C}$ 'de iki günlük inkübasyondan sonra değerlendirme yapılmıştır. Patateste inokule edilen bölgedeki yumuşama gösteren bakteri izolatları pozitif olarak kabul edilmiştir.

Litmus Milk testinde bakteri izolatları litmus milk içeren besi yerine bir özeyle her bir izolat 3 tekrarl olacak şekilde ekim yapılmıştır. Tüpler inkibatörde $27 \pm 1^{\circ} \mathrm{C}$ 'de 2 gün geliștirilmiş ve tüplerdeki besi yerinin rengini maviye dönüştüren izolatlar alkali, kırmızıya dönüştüren izolatlar ise asit oluşturan olarak değerlendirilmiştir (Moore ve ark., 2001).

Tütünde aşırı duyarlılık testinde hastalıklı bitkilerden izole edilen bakteriyel izolatların aşırı duyarlılık reaksiyonunun belirlemesi için tütün (Nicotiana tabacum cv Samsun N) bitkisi yaprağının alt yüzeyine damar aralarına biber bakteriyel leke izolatlarının $10^{8}$ hücre $/ \mathrm{ml}$ yoğunluğundaki süspansiyonu bir enjektör yardımı ile infiltre edilmiştir. Tütün yapraklarında24 saat sonra inokule edilen alanlarda nekrotik görünüm gösteren izolatlar pozitif olarak kabul edilmiştir (Klement ve Goodman, 1967). Pozitif kontrol olarak 1a-2-2r izolatı ve negatif kontrol olarak da fizyolojik su kullanılmıştır.

Patojenite testinde biber bitkisi kullanılmıştır. Biber bitkileri 4-5 yapraklı döneme ulaştığında 36-48 saatlik bakteri kültürlerinden $10^{8}$ hücre/bakteri yoğunluğunda hazırlanan süspansiyon yaprak alt yüzeyinden epidermise enjekte edilmiştir. İnoküle edilen alanlarda 14-21 gün sonra nekrotik görünümler oluşmuştur. Pozitif kontrol olarak, 1a-2-2r referans izolat kullanılmıştır.

\section{BULGULAR ve TARTIŞMA}

Kahramanmaraş Tevekkeli mahallesinden 8, Pazarcık ilçesi Doğanlı Karahasan mahallesinden 10, Seyran tepe mahallesinden 13, Çakmak mahallesinden 12, Türkoğlu ilçesine bağlı Kuyumcular mahallesinden 14, Gaziantep ili Nurdağı ilçesine bağlı Balıkalan mahallesinden 22, Mogaylar mahallesinden 24 tane bakteriyel izot elde edilmiştir. Toplamda biberden 103 bakteriyel izolat elde edilmiştir.

Bakteriyel izolatların klasik tanılanmasında koloni gelişimi testleri olan YDC agar besi yerin de sarı, konveks, Nutrient Agar besi yerinde ise sar1, mukoid koloniler geliştiği gözlenmiştir. Tween $\mathrm{B}$ besi yerinde yuvarlak, sarı, tümsek ve çevresinde temiz haleli koloniler geliştirmiştir. King $\mathrm{B}$ besi yerine çizilen bakteriyel leke izolatları açık sarı, krem renkli, floresan özellik göstermeyen koloniler oluşmuştur (Tablo 1).

Potasyum Hidroksit testinde $(\mathrm{KOH})$ bakteri izolatları özeye yapışarak sümüksü bir yapı oluşturduğundan Gram negatif olarak kabul edilmiştir (Mirik, 2005). Bu çalışmada kullanılan izolatların Gram negatif olduğu gözlenmiştir.

Oksidaz testinde bakteriyel izolatlar oksidaz test solüsyonu emdirilmiş filtre kağıdına çizilmesi sonucu hiçbir renk değişimi meydana getirmemiş ve bundan dolayı tüm izolatlar oksidaz negatif olarak değerlendirilmiştir (Küsek, 2007).

Oksidatif/fermantatif testinde $26^{\circ} \mathrm{C}$ 'de altı günlük bir inkübasyondan sonra değerlendirme yapılmış ve bütün bölge bakteriyel leke izolatları oksijenli (vasparsız) besi yerinde gelişim göstererek tüplerin rengini sarıya çevirmişlerdir. Oksijensiz (vasparlı) besi yerinde, elde edilen izolatların tamamı gelişmediğinden besi yerinin renginde bir değişme olmamıştır(Sands,1990). Biberden izole edilen izolatların oksidatif özellikte olduğu gözlenmiştir.

Nișasta hidrolizasyonu testinde nişasta besi yerine ekilen referans kültür 7-14 günlük inkübasyon sonunda üzerine lugol eriği döküldüğünde koloni çevresinde belirgin parlak bir alan gözlendiği ve çalışma alanından izole edilen bakteriyel leke izolatları etrafinda parlak alan geç ortaya çıkmıştır. Bundan dolayı bölge izolatları zayıf pozitif olarak değerlendirilmiştir (Lelliot ve Stead, 1987).

Pektolitik aktivite testine göre bakteriyel leke izolatların hiç biri patates dilimleri üzerinde yumuşak çürüklük oluşturmamıştır. Pozitif kontrol olarak kullanılan Erwinia caratovora subsp. caratovora patates dilimlerinde yumuşamaya neden olmuştur (Mirik, 2005).

Katalaz testinde NA besiyerinde 24 saat geliştirildikten sonra \%3'lük $\mathrm{H}_{2} \mathrm{O}_{2}$ döküldüğünde birkaç saniye içerisinde gaz kabarcıkları gösteren izolatlar katalaz pozitif olarak kabul edilmiștir (Lelliot ve Stead, 1987). Çalışma alanından izole edilen tüm izolatlar katalaz pozitif olduğu belirlenmiştir.

Litmus Milk Reaksiyon testinde hastalıklı dokulardan izole edilen bakteri izolatları litmus milk besi yeri içine bir özeyle her bir izolat 3 tekrarlı olacak şekilde ekim yapılmıştır. Tüpler inkibatörde $27 \pm 1^{\circ} \mathrm{C}$ 'de 2 gün geliştirilmiş ve tüplerdeki besi yerinin rengini maviye dönüștürenler alkali, kırmızıya dönüștürenler ise asit oluşturan olarak değerlendirilmiştir (Moore ve ark., 2001). Sıvı litmus milk içeren besi yerinde 2 gün 
inkübe edilen bölge ve referans izolat (1a-2-2r) litmus milk besi yerini alkali yapmıştır.

Tütünde Aşırı Duyarlılık (Hypersensitive ReactionHR) testine göre bölge izolatlarının tümü ve referans kültürler tütün bitkisine inokule edildikten 24-36 saat sonra tütün yapraklarında tipik aşırı duyarlılık reaksiyonuna neden olmuştur. Negatif kontrol olarak kullanılan fizyolojik su uygulanan tütün yapraklarında herhangi bir aşırı duyarlılık reaksiyonu gözlemlenmemiştir.
Patojenite çalışmasında 3-5 yapraklı dönemdeki biber bitkileri kullanılmıştır. Bunun için 36-48 saatlik bakteri kültürlerinden $10^{8}$ hücre/bakteri yoğunluğunda hazırlanan süspansiyon yaprak alt yüzeyinden epidermise enjekte edilmiştir. Çalışmada kullanılan bölge izolatları ve referans kültür (1a-2-2r) ile yapılan biberde patojenite testinde 101izolatinokulasyondan 14 -21 gün sonra bitkilerin yapraklarında kahverengi nekrotik lekeler oluşmuştur.

Tablo 1. Bakteriyel izolatların klasik tanılanmasında kullanılan testlerin sonuçları

\begin{tabular}{|c|c|c|c|c|c|c|c|c|c|}
\hline $\begin{array}{l}\text { Izolatların } \\
\text { kod adları }\end{array}$ & $\begin{array}{l}\text { Pektolitik } \\
\text { aktivite }\end{array}$ & Gram & Katalaz & $\mathrm{O} \backslash \mathrm{F}$ & $\begin{array}{c}\text { Tütünde } \\
\text { Aşırı } \\
\text { Duyarlılık }\end{array}$ & Oksidaz & $\begin{array}{c}\text { Litmus } \\
\text { Milk }\end{array}$ & Nişasta & Patojenite \\
\hline AU1 & - & - & + & $\mathrm{O}$ & + & - & ALK & $\mathrm{Z}$ & + \\
\hline AU2 & - & - & + & $\mathrm{O}$ & + & - & ALK & $\mathrm{Z}$ & + \\
\hline AU3 & - & - & + & $\mathrm{O}$ & + & - & ALK & $\mathrm{Z}$ & + \\
\hline AU4 & - & - & + & $\mathrm{O}$ & + & - & ALK & $\mathrm{Z}$ & + \\
\hline AU5 & - & - & + & $\mathrm{O}$ & + & - & ALK & $\mathrm{Z}$ & + \\
\hline AU6 & - & - & + & $\mathrm{O}$ & + & - & ALK & $\mathrm{Z}$ & + \\
\hline AU7 & - & - & + & $\mathrm{O}$ & + & - & ALK & $\mathrm{Z}$ & + \\
\hline AU8 & - & - & + & $\mathrm{O}$ & + & - & ALK & $\mathrm{Z}$ & + \\
\hline AU10 & - & - & + & $\mathrm{O}$ & + & - & ALK & $\mathrm{Z}$ & + \\
\hline AU11 & - & - & + & $\mathrm{O}$ & + & - & ALK & $\mathrm{Z}$ & + \\
\hline AU12 & - & - & + & $\mathrm{O}$ & + & - & ALK & $\mathrm{Z}$ & + \\
\hline AU13 & - & - & + & $\mathrm{O}$ & + & - & ALK & $\mathrm{Z}$ & + \\
\hline AU14 & - & - & + & $\mathrm{O}$ & + & - & ALK & $\mathrm{Z}$ & + \\
\hline AU15 & - & - & + & $\mathrm{O}$ & + & - & ALK & $\mathrm{Z}$ & + \\
\hline AU16 & - & - & + & $\mathrm{O}$ & + & + & ALK & $\mathrm{Z}$ & + \\
\hline AU17 & - & - & + & $\mathrm{O}$ & + & - & ALK & $\mathrm{Z}$ & + \\
\hline AU18 & - & - & + & $\mathrm{O}$ & + & - & ALK & $\mathrm{Z}$ & + \\
\hline AU19 & - & - & + & $\mathrm{O}$ & + & - & ALK & $\mathrm{Z}$ & + \\
\hline AU22 & - & - & + & $\mathrm{O}$ & + & - & ALK & $\mathrm{Z}$ & + \\
\hline AU23 & - & - & + & $\mathrm{F}$ & + & - & $\mathrm{AC}$ & + & + \\
\hline AU24 & - & - & + & $\mathrm{O}$ & + & - & ALK & $\mathrm{Z}$ & + \\
\hline AU25 & - & - & + & $\mathrm{O}$ & + & - & ALK & $\mathrm{Z}$ & + \\
\hline AU26 & - & - & - & $\mathrm{F}$ & - & + & $\mathrm{AC}$ & $\mathrm{Z}$ & - \\
\hline AU27 & - & - & + & $\mathrm{O}$ & + & - & ALK & $\mathrm{Z}$ & + \\
\hline AU28 & - & - & + & $\mathrm{O}$ & + & - & ALK & $\mathrm{Z}$ & + \\
\hline AU29 & - & - & + & $\mathrm{O}$ & + & - & ALK & $\mathrm{Z}$ & + \\
\hline AU30 & - & - & + & $\mathrm{O}$ & + & - & ALK & $\mathrm{Z}$ & + \\
\hline AU31 & - & - & + & $\mathrm{O}$ & + & - & ALK & $\mathrm{Z}$ & + \\
\hline AU32 & - & - & + & $\mathrm{O}$ & + & - & ALK & $\mathrm{Z}$ & + \\
\hline AU33 & - & - & + & $\mathrm{O}$ & + & - & ALK & $\mathrm{Z}$ & + \\
\hline AU34 & - & - & + & $\mathrm{O}$ & + & - & ALK & $\mathrm{Z}$ & + \\
\hline AU35 & - & - & + & $\mathrm{O}$ & - & - & ALK & $\mathrm{Z}$ & + \\
\hline AU36 & - & - & + & $\mathrm{F}$ & + & - & ALK & $\mathrm{Z}$ & + \\
\hline AU37 & - & - & + & $\mathrm{O}$ & + & - & ALK & $\mathrm{Z}$ & + \\
\hline AU38 & - & - & + & $\mathrm{O}$ & + & - & ALK & $\mathrm{Z}$ & + \\
\hline AU39 & - & - & + & $\mathrm{O}$ & + & - & Alk & $\mathrm{Z}$ & + \\
\hline AU40 & - & - & + & $\mathrm{O}$ & + & - & ALK & $\mathrm{Z}$ & + \\
\hline
\end{tabular}


Tablo 1. (devam)

\begin{tabular}{|c|c|c|c|c|c|c|c|c|c|}
\hline AU41 & - & - & + & $\mathrm{O}$ & + & - & ALK & $\mathrm{Z}$ & + \\
\hline AU42 & - & - & + & $\mathrm{O}$ & + & - & ALK & $\mathrm{Z}$ & + \\
\hline AU43 & - & - & + & $\mathrm{O}$ & + & - & ALK & $\mathrm{Z}$ & + \\
\hline AU44 & - & - & + & $\mathrm{O}$ & + & - & ALK & Z & + \\
\hline AU45 & - & - & + & $\mathrm{O}$ & + & - & ALK & $\mathrm{Z}$ & + \\
\hline AU46 & - & - & + & $\mathrm{O}$ & + & - & ALK & $\mathrm{Z}$ & + \\
\hline AU47 & - & - & + & $\mathrm{O}$ & + & - & ALK & $\mathrm{Z}$ & + \\
\hline AU48 & + & + & - & $\mathrm{F}$ & - & + & $\mathrm{AC}$ & + & - \\
\hline AU49 & - & - & + & $\mathrm{O}$ & + & - & ALK & $\mathrm{Z}$ & + \\
\hline AU50 & - & - & + & $\mathrm{O}$ & + & - & ALK & $\mathrm{Z}$ & + \\
\hline AU51 & - & - & + & $\mathrm{O}$ & + & - & ALK & $\mathrm{Z}$ & + \\
\hline AU52 & - & - & + & $\mathrm{O}$ & + & - & ALK & $\mathrm{Z}$ & + \\
\hline AU53 & - & - & + & $\mathrm{O}$ & + & - & Alk & $\mathrm{Z}$ & + \\
\hline AU54 & - & - & + & $\mathrm{O}$ & + & - & Alk & $\mathrm{Z}$ & + \\
\hline AU55 & - & - & + & $\mathrm{O}$ & + & - & ALK & $\mathrm{Z}$ & + \\
\hline AU56 & - & - & + & $\mathrm{O}$ & + & - & ALK & $\mathrm{Z}$ & + \\
\hline AU57 & - & - & + & $\mathrm{O}$ & + & - & ALK & $\mathrm{Z}$ & + \\
\hline AU58 & - & - & + & $\mathrm{O}$ & + & - & Alk & $\mathrm{Z}$ & + \\
\hline AU59 & - & - & + & $\mathrm{O}$ & + & - & ALK & $\mathrm{Z}$ & + \\
\hline AU60 & - & - & + & $\mathrm{O}$ & + & - & ALK & $\mathrm{Z}$ & + \\
\hline AU61 & - & - & + & $\mathrm{O}$ & + & - & ALK & $\mathrm{Z}$ & + \\
\hline AU62 & - & - & + & $\mathrm{O}$ & + & - & ALK & $\mathrm{Z}$ & + \\
\hline AU63 & - & - & + & $\mathrm{O}$ & + & - & ALK & $\mathrm{Z}$ & + \\
\hline AU64 & - & - & + & $\mathrm{O}$ & + & - & ALK & $\mathrm{Z}$ & + \\
\hline AU65 & - & - & + & $\mathrm{O}$ & + & - & Alk & $\mathrm{Z}$ & + \\
\hline AU66 & - & - & + & $\mathrm{O}$ & + & - & ALK & $\mathrm{Z}$ & + \\
\hline AU67 & - & - & + & $\mathrm{O}$ & + & - & ALK & $\mathrm{Z}$ & + \\
\hline AU68 & - & - & + & $\mathrm{O}$ & + & - & ALK & $\mathrm{Z}$ & + \\
\hline AU69 & - & - & + & $\mathrm{O}$ & + & - & ALK & $\mathrm{Z}$ & + \\
\hline AU70 & - & - & + & $\mathrm{O}$ & + & - & ALK & $\mathrm{Z}$ & + \\
\hline AU71 & - & - & + & $\mathrm{O}$ & + & - & ALK & $\mathrm{Z}$ & + \\
\hline AU72 & - & - & + & $\mathrm{O}$ & + & - & ALK & $\mathrm{Z}$ & + \\
\hline AU73 & - & - & + & $\mathrm{O}$ & + & - & ALK & $\mathrm{Z}$ & + \\
\hline AU77 & - & - & + & $\mathrm{O}$ & + & - & ALK & $\mathrm{Z}$ & + \\
\hline AU78 & - & - & + & $\mathrm{O}$ & + & - & ALK & $\mathrm{Z}$ & + \\
\hline AU79 & - & - & + & $\mathrm{O}$ & + & - & ALK & $\mathrm{Z}$ & + \\
\hline AU82 & - & - & + & $\mathrm{O}$ & + & - & ALK & $\mathrm{Z}$ & + \\
\hline AU83 & - & - & + & $\mathrm{O}$ & + & - & ALK & $\mathrm{Z}$ & + \\
\hline AU84 & - & - & + & $\mathrm{O}$ & + & - & ALK & $\mathrm{Z}$ & + \\
\hline AU85 & - & - & + & $\mathrm{O}$ & + & - & ALK & $\mathrm{Z}$ & + \\
\hline AU86 & - & - & + & $\mathrm{O}$ & + & - & ALK & $\mathrm{Z}$ & + \\
\hline AU87 & - & - & + & $\mathrm{O}$ & + & - & ALK & $\mathrm{Z}$ & + \\
\hline AU88 & - & - & + & $\mathrm{O}$ & + & - & ALK & $\mathrm{Z}$ & + \\
\hline AU89 & - & - & + & $\mathrm{O}$ & + & - & ALK & $\mathrm{Z}$ & + \\
\hline AU90 & - & - & + & $\mathrm{O}$ & + & - & ALK & $\mathrm{Z}$ & + \\
\hline AU91 & - & - & + & $\mathrm{O}$ & + & - & ALK & $\mathrm{Z}$ & + \\
\hline AU92 & - & - & + & $\mathrm{O}$ & + & - & ALK & $\mathrm{Z}$ & + \\
\hline AU93 & - & - & + & $\mathrm{O}$ & + & - & ALK & $\mathrm{Z}$ & + \\
\hline AU94 & - & - & + & $\mathrm{O}$ & + & - & ALK & $\mathrm{Z}$ & + \\
\hline
\end{tabular}


Tablo 1. (devam)

\begin{tabular}{|c|c|c|c|c|c|c|c|c|c|}
\hline AU95 & - & - & + & $\mathrm{O}$ & + & - & Alk & $\mathrm{Z}$ & + \\
\hline AU96 & - & - & + & $\mathrm{O}$ & + & - & ALK & $\mathrm{Z}$ & + \\
\hline AU97 & - & - & + & $\mathrm{O}$ & + & - & ALK & $\mathrm{Z}$ & + \\
\hline AU98 & - & - & + & $\mathrm{O}$ & + & - & ALK & $\mathrm{Z}$ & + \\
\hline AU99 & - & - & + & $\mathrm{O}$ & + & - & ALK & $\mathrm{Z}$ & + \\
\hline AU100 & - & - & + & $\mathrm{O}$ & + & - & ALK & $\mathrm{Z}$ & + \\
\hline AU101 & - & - & + & $\mathrm{O}$ & + & - & ALK & $\mathrm{Z}$ & + \\
\hline AU102 & - & - & + & $\mathrm{O}$ & + & - & ALK & Z & + \\
\hline AU103 & - & - & + & $\mathrm{O}$ & + & - & ALK & Z & + \\
\hline AU104 & - & - & + & $\mathrm{O}$ & + & - & ALK & $\mathrm{Z}$ & + \\
\hline AU105 & - & - & + & $\mathrm{O}$ & + & - & ALK & Z & + \\
\hline AU106 & - & - & + & $\mathrm{O}$ & + & - & ALK & Z & + \\
\hline AU107 & - & - & + & $\mathrm{O}$ & + & - & ALK & Z & + \\
\hline AU108 & - & - & + & $\mathrm{O}$ & + & - & ALK & Z & + \\
\hline AU109 & - & - & + & $\mathrm{O}$ & + & - & ALK & Z & + \\
\hline AU110 & - & - & + & $\mathrm{O}$ & + & - & ALK & Z & + \\
\hline AU111 & - & - & + & $\mathrm{O}$ & + & - & ALK & Z & + \\
\hline AU112 & - & - & + & $\mathrm{O}$ & + & - & Alk & $\mathrm{Z}$ & + \\
\hline AU113 & - & - & + & $\mathrm{O}$ & + & - & ALK & $\mathrm{Z}$ & + \\
\hline AU114 & - & - & + & $\mathrm{O}$ & + & - & ALK & $\mathrm{Z}$ & + \\
\hline $1 a-22 r$ & - & - & + & $\mathrm{O}$ & + & - & ALK & + & + \\
\hline GSPB2097 & & - & + & & & - & & + & \\
\hline NCPPB1395 & & - & + & & & - & & + & \\
\hline ECC1025 & & - & + & & & - & & + & \\
\hline PAT ERW & & - & + & & & - & & - & \\
\hline
\end{tabular}

+ (pozitif) ve - (negatif)

Elde edilen izolatların morfolojik, fizyolojik ve biyokimyasal yöntemlerin yanı sıra, tütünde $\mathrm{HR}$ ve patojenite test sonuçlarına göre 103 izolattan 100 tanesi referans izolatlarla benzer sonuçlar vermesi nedeni ile Xanthomonas axonopodis olarak teşhis edilmiştir. Akdeniz bölgesinde yapılan bir çalışmada da biberlerden izole edilen etmenin Xanthomonas axonopodis olduğu bildirilmiştir (Mirik, 2005).

\section{KAYNAKLAR}

Anonim, 2009. Biber yetiştiriciliği http://organicgroup.eu/?dizayn $=$ detay $\&$ id $=451$

Aysan, Y., Sahin, F., 2003. Occurrence of bacterial spot disease, caused by Xanthomonas axonopodis pv. vesicatoria, on pepper in the eastern Mediterranean region of Turkey. Plant Pathology, 52: 781.

Aysan, Y., Çınar, Ö., 2001. Çukurova bölgesinde biberlerde bakteriyel leke hastalığının (Xanthomonas axonopodis pv. vesicatoria) çıkışı ve kontrolü üzerine araştırmalar. Türkiye IX. Fitopatoloji Kongresi, Tekirdağ, S:549-554.

Cook, A.A., Stall, R.E., 1982. Distribution of races of Xanthomonas vesicatoria pathogenic on pepper. Plant Disease, 66: 388-389
Cook, R. J., Baker, K. F., 1983. Nature and practice of biological control of plant pathogens. American Phytopathological Society, 539.

Jones, J. B.,Scott, J.W., 1986. Hypersensitive response in tomato to Xanthomonas campestris pv. vesicatoria. Plant Disease, 70: 337-339.

Klement, Z., Goodman, R. N., 1967. The hypersensitive reaction to infection by bacterial plant pathogens. Annual Review of Phytopathology, 5: 17-44.

Kovacs, N., 1956. Identification of Pseudomonas pyocyanea by the oxidase reaction. Nature (London), 178:703.

Küsek, M., 2007. Asmada (Vitis vinifera L.) ura neden olan Agrobacterium vitis'in tanılanması ve mücadele olanaklarının araştırılması. Çukurova Üniversitesi Fen Bilimleri Enstitüsü Bitki Koruma ABD, Doktora Tezi, 103s.

Lelliot, R.A., Stead, D.E., 1987. Diagnostic procedures for bacterial plant disease. Methods for the Diagnosis of Bacterial Diseases of Plants 58-59. Blackwell Scientific Publications, 216s.

Mcguire, R. G., Jones, J. B., Sasser, M., 1986. Tween media for semiselective isolation of Xanthomonas campestris pv. vesicatoria from soil and plant material. Plant Disease, 70: 887-891. 
Mirik, M., 2005. Biberde bakteriyel leke etmeni Xanthomonas axonopodis pv.vesicatoria'nın tanılanması ve bitki büyüme düzenleyici rhizobacteriler ile biyolojik mücadele olanakları. Çukurova Üniversitesi Fen Bilimleri Enstitüsü Bitki Koruma ABD, Doktora Tezi, 162s.

Moore, L. W.,Bouzar, H., Burr, T., 2001. Gramnegative bacteria, Agrobacterium. (N. W. Schaad, J. B. Jones, W. Chuneditor), Laboratory Guide for Identification of Plant Pathogenic Bacteria, Third Edition, APS Press. ST. Paul, Minnesota, p:17-35.

Pohronezny, K., Hewitt, M., Infante, J., Datnoff, L., 1992.Wind and wind-generated sand injury as factors in infection of pepper by Xanthomonas campestris pv. vesicatoria. Plant Disease, 76: 10361039.

Sands, D. C., 1990. Physiological criteria-determinate tests. In Methods in Phytobacteriology. (Edts. Klement, Z.,Rhudolph, K.,Sands, D. C.). Academia Kiado, Budapest, Hungary.
Saygıl1, H., Köseoğlu, T., Demir, G., 1985. Bat1 Anadolu Bölgesi domates ekim alanlarında hastalık etmeni olan bakterilerin toprakta yaşam durumları ve kullanılan suni gübrelerin bu etmenlere etkileri üzerinde araştırmalar. Doğa Bilim Dergisi, D2,(9):367-383.

Stall, R. E., 1993. Xanthomonas campestris pv. vesicatoria: cause of bacterial spot of tomato and pepper. In: Xanthomonas (Edts; J.G. Swingand, E.L.Civerolo. Great Britain by St.

Şahin, F., 1997. Detection, identification and characterization of strains of Xanthomonas campestris pv. vesicatoria by traditional and moleculer methods, and resistance in Capsicum species to Xanthomonas campestris pv. vesicatoria pepper race 6. $\mathrm{PhD}$. Thesis. The Ohio State University. p:181. 